\title{
Et ædelt fag under stigende pres? Udviklingen i journalisternes professionelle idealer og deres opfattelser af det daglige arbejde som journalist 2009-2015
}

AF MORTEN SKOVSGAARD, ARJEN VAN DALEN OG KATRINE BISGAARD

\section{Resumé}

Mediebranchen er under pres, journalistikkens mangler bliver taget under behandling i mange indlæg i debatten, og mange journalister mener selv, at den journalistiske kvalitet er blevet ringere over de senere år. Man får indtryk af en profession i forfald. Ofte er pessimismen dog baseret på retrospektive vurderinger, som kan være problematiske.

Via to spørgeskemaundersøgelser blandt et repræsentativt udsnit af de danske journalister - en fra 2009 og en fra 2015 viser vi, at journalisterne i 2015 ikke oplever mere indflydelse fra konkurrence eller læser-/seer-/lytter-/brugertal end i 2009. Og selvom journalisterne oplever mere indflydelse fra deadlines og mediets redaktionelle linje, er de professionelle idealer stabile. Resultaterne er ikke i sig selv en afvisning af en profession under pres, men de peger på, at den journalistiske profession er mere modstandsdygtig, end det ofte bliver fremstillet i den offentlige debat.

\section{Introduktion}

"Journalistik er et ædelt fag under et helt enormt pres". Bag denne overskrift fra fagbladet Journalistens hjemmeside gemmer sig filosofiprofessor Vincent F. Hendricks' dystre diagnose af en krise i dansk journalistik, som blandt andet bunder i kampen 
om opmærksomhed, klik og penge på et marked, hvor alle kan publicere information via internettet (Skadhede, 2016a). Andre istemmer bekymringen om journalistikken på afveje (Larsen, 2017), eller at journalistikken er i et kapløb mod bunden (Kragh, 2014). Og beder man journalisterne selv om at vurdere udviklingen, er krisetegnene også til at få øje på. Mange har en oplevelse af et stigende produktionspres og faldende journalistisk kvalitet (Mollerup m.fl., 2016: 4. Se dog Willig m.fl., 2015 for en mere optimistisk vurdering af den journalistiske kvalitet blandt journalister). På baggrund af kritikernes og journalisternes egne bekymringer kan man frygte, at der foregår en hastig erodering af den journalistiske profession.

Man sætter da også kikkerten for det blinde øje, hvis man ignorerer, at der er sket en betydelig udvikling i betingelserne for at bedrive journalistik, og at forandringerne især har accelereret gennem de seneste 10 år, selvom debatten om journalistikkens forfald er noget ældre end det (se eksempelvis Fallows, 1996; Patterson, 2003). Internationale teknologigiganter som Facebook og Google har gjort et stort indhug i det danske annoncemarked og samtidig reduceret de traditionelle mediers kontrol over deres brugere (Slots- og Kulturstyrelsen, 2017).

Men selvom det baseret på kritiske røster, analyser og endda journalisternes egen opfattelse er nærliggende at konkludere, at journalistikken er fanget i en hastigt nedadgående spiral, er der grund til at trække vejret, inden man slår to streger under facit. I debatten om journalistikkens tilstand møder man ofte konklusioner baseret på generaliseringer ud fra enkelte eksempler og analyser af udviklingen, der bygger på øjebliksbilleder af den nuværende situation sammenlignet med erindringen om, hvordan det så ud engang i nær eller mere fjern fortid.

Selv når man spørger journalisterne om deres opfattelse af, hvad der er sket med journalistikken over en årrække, skal man være påpasselig med at tage svarene som udtryk for en reel udvikling. Der er ofte problemer med validiteten i den type retrospektivt data (se for eksempel Bernard m.fl., 1984), særligt fordi svarene har det med at blive påvirket af folks nuværende opfattelser og holdninger (se for eksempel Pudney, 2011). I journalisternes tilfælde er det således sandsynligt, at deres opfattelse er påvirket af den nutidige debat om journalistikkens udvikling. 
Derfor er det vigtigt at supplere med analyser, der bygger på data over tid, hvor man har mulighed for at sammenligne svar om den aktuelle situation indsamlet med et antal års mellemrum. På den måde kan man lave en sammenligning og få en bedre forståelse af, hvad der har ændret sig, i stedet for at basere konklusionerne udelukkende på retrospektive spørgsmål.

I et eksempel på en analyse, der bygger på en sammenligning af svar fra to forskellige tidspunkter frem for retrospektive vurderinger, blev danske folketingspolitikere i 1980 og 2000 stillet de samme spørgsmål om deres forhold til medierne. ElmelundPræstekær m.fl. (2011) viste, at folketingsmedlemmerne - modsat forventningen baseret på den offentlige debat - var mere tilfredse med mediedækningen af dem selv, og at de ikke fandt mediernes dækning af politik mere fordrejet, når man sammenlignede svarene fra 2000 med svarene fra 1980. En anden undersøgelse, der ligesom vores fokuserede på journalister, brugte samme fremgangsmåde til at analysere udviklingen i svenske journalisters arbejdsmiljø over tid. Undersøgelsen viste en stor stabilitet i svenske journalisters oplevelse af deres arbejdsmiljø mellem 1989 og 2005, selvom deres arbejdsbetingelser også i den periode blev drastisk forandret (Nilsson, 2007:78).

Indtil nu har det i dansk sammenhæng ikke været muligt at lave lignende analyser af ændringer i journalisternes opfattelse af journalistikken. To spørgeskemaundersøgelser af danske journalister foretaget i henholdsvis 2009 og 2015 åbner dog muligheden for at foretage netop denne type analyse. Begge år har journalisterne svaret på en række spørgsmål om deres opfattelse af det daglige arbejde som journalist. Det giver et stærkt grundlag for at analysere, hvorvidt denne opfattelse har forandret sig $\mathrm{i}$ perioden fra 2009 til 2015, der har budt på store omvæltninger i mediebranchen.

Målet med artiklen er således at svare på, hvordan danske journalisters professionelle idealer og deres opfattelse af indflydelse på deres daglige arbejde som journalist har aendret sig mellem 2009 og 2015. Vores indsamling af data med seks års mellemrum giver os mulighed for at bidrage med et nyt perspektiv, som kan indgå i debatten om journalistikkens udvikling.

Som det første vil vi via forskningslitteraturen beskrive journalistikkens professionsværdier og diskutere, hvordan de struktu- 
relle udviklinger kan forventes at påvirke disse værdier og muligheden for at leve op til dem i praksis. Derefter analyserer vi med udgangspunkt i de to spørgeskemaundersøgelser udviklingen i journalisternes rolleopfattelser, deres opfattelse af forskellige typer af pres og indflydelse på deres daglige arbejde. Som det sidste diskuterer vi resultaterne fra analysen.

\section{Journalistik som profession}

Det har i mange år været debatteret, om journalistik skal opfattes som en profession, en semi-profession eller et erhverv (for eksempel Aldridge \& Evetts, 2003; Tumber \& Prentoulis, 2005). Denne diskussion er væsentlig for at forstå, hvad der sker, når professionelle normer kommer under pres.

På den ene side påpeger såvel beskrivelser som empiriske undersøgelser af journalister, at de traditionelt har udvist bred opbakning til at følge professionelle normer i deres arbejde, som for eksempel at arbejde i offentlighedens tjeneste, at være samfundets og demokratiets vagthund, at sikre (tilstræbt) objektiv oplysning og facilitere den offentlige debat (for eksempel Deuze, 2005; Tumber \& Prentoulis, 2005; Weaver \& Willnat, 2012). I 2009 gennemførte Skovsgaard m.fl. (2012) den spørgeskemaundersøgelse, som sammen med den nyere spørgeskemaundersøgelse fra 2015 indgår i datagrundlaget for analysen i denne artikel. Formålet med undersøgelsen i 2009 var at tegne en detaljeret profil af danske journalister og deres professionelle værdier og opfattelser af deres arbejde. Undersøgelsens resultater pegede på en journalistisk profession med stærke professionsværdier, og hvor journalister havde en forholdsvis høj grad af frihed til at forfølge deres idealer, også selvom forskellige interne faktorer såsom deadlines, målsætning om at generere læsere, lyttere, seere og/ eller klik samt mediets redaktionelle linje havde en vis indflydelse. Disse professionelle idealer skaber grundlaget for en professions legitimitet og dens professionelle autonomi (Skovsgaard \& Bro, 2011), og hvis journalistik skal betragtes som en profession, er det afgørende, at de professionelle normer nyder stærk opbakning blandt journalister (for eksempel Deuze, 2005). 
På den anden side udgør journalister af flere grunde en mere sårbar profession end eksempelvis læger og advokater, der ofte er blevet fremhævet som de klassiske professioner i professionslitteraturen (Aldridge \& Evetts, 2003). I modsætning til læger og advokater skal journalister ikke opnå en statsautorisation for at kunne arbejde som journalister. Alle kan i princippet blive journalist, og journalister kan ikke fratages en licens, hvilket betyder, at de professionelle normer og idealer er mindre beskyttede end $i$ de klassiske professioner (Aldridge \& Evetts, 2003). Nok så vigtigt arbejder journalister i modsætning til læger og advokater ikke for enkelte klienter, men er afhængige af at arbejde for en organisation, som kan give dem adgang til den offentlighed, de hævder at tjene (Hallin \& Mancini, 2004: 35). Den afhængighed betyder, at når de professionelle idealer og organisationens mål kommer i konflikt, kan de professionelle idealer og dermed også journalisternes samfundsmæssige legitimitet komme under pres (Cook, 1998).

Professionslitteraturen fremhæver den potentielle modsætning mellem en økonomisk markedslogik og den professionelle logik, hvor en økonomisk markedslogik kan true med at undergrave de idealer, som den professionelle logik bygger på (for eksempel Freidson, 2001).

\section{Professionsværdier under pres?}

Over de seneste år har en lang række danske medier oplevet problemer med at opretholde deres forretningsmodel og indtjening. Internettet har ændret befolkningens måde at finde nyheder på og dermed journalisternes måde at nå borgerne på. Fra 2007 til 2014 har de største dagblade mistet mellem 18 og 57 procent af deres hverdagsoplag (Skadhede, 2016b). I 2017 svarede mere end halvdelen af befolkningen, at de i løbet af den seneste uge havde anvendt deres telefon til at tilgå nyheder, hvilket var en markant stigning over bare nogle få år (Schrøder m.fl., 2017: 16-17). Samtidig med at borgere i høj grad har flyttet sig fra print til internet, er en del af annoncerne flyttet samme vej, men her er det sværere for de klassiske medier at opnå den samme indtjening som på printannoncer (se for eksempel Franklin, 2014; 
Nielsen, 2012). Internettet har også betydet, at de medier, som tidligere fokuserede på enten print, tv eller radio, nu også kan udkomme digitalt og gøre det løbende uden begrænsende deadlines. Det gør det lettere at monitorere og konkurrere med de andre mediers nyheder (Blach-Ørsten, 2013: 105). Samtidig har internettet også givet andre aktører meget nemmere adgang til at formidle til et større publikum - blandt andet gennem sociale medier. Derved er konkurrencen generelt øget, og kampen om at være hurtigst med nyhederne og få flest klik er radikaliseret (se eksempelvis Bakker, 2012; Blach-Ørsten, 2013; Hartley, 2011, Kammer, 2013; Levy \& Nielsen, 2010). Udviklingen har fået Blach-Ørsten til at konkludere, at vi er på vej væk fra det traditionelle uafhængige nyhedsregime hen imod et konkurrencebaseret nyhedsregime (2013: 105).

Det har ført til en stor opmærksomhed på læsertal, særligt på nettet, hvor historier hurtigt kan op- og nedprioriteres eller ændres baseret på deres popularitet (se for eksempel Hartley, 2011; Kammer, 2013; Vu, 2014). Samtidig peger Blach-Ørsten (2013) på en udvikling hen mod mere sensationsprægede og tabloide nyheder. Det økonomiske pres har, som beskrevet i indledningen af denne artikel, fået mange til at frygte en erodering af de professionelle idealer, fordi de kommer i konflikt med kravet om at tjene penge. Som en amerikansk redaktør har udtrykt det: "I den her branche [...] må du tænke med et kasseapparat i hovedet" (McManus, 1997: 5, vores oversættelse). Daniel Hallin (2000) har ligeledes argumenteret for, at det økonomiske pres, som amerikanske medier var udsat for, forandrede balancen mellem den økonomiske logik og den professionslogik, som de amerikanske journalister arbejder ud fra. For det første voksede betydningen af nogle roller, som ikke traditionelt var en del af de professionelle journalistiske normer, eksempelvis underholdningsrollen. For det andet blev amerikanske journalisters frihed til at leve op til deres professionelle idealer i stigende grad begrænset af det økonomiske pres. At begrænsningerne i journalisters frihed til at arbejde i overensstemmelse med deres professionelle værdier er vokset, blev for nylig bekræftet i en spørgeskemaundersøgelse, som har været gennemført blandt amerikanske journalister siden 1971 (Weaver and Wilhoit, 2014). Hvor $60 \%$ af amerikanske journalister i 1971 oplevede en stor frihed til at 
vælge, hvilke historier de ville arbejde på, var antallet faldet til 33 \% i 2013. Undersøgelsen viste dog også, at det voksende pres på journalisterne ikke har betydet lavere opbakning til de professionelle idealer. Tværtimod var det i 2013 eksempelvis vigtigere end nogensinde for amerikanske journalister at analysere komplekse problemer og agere vagthund over for regeringen. Witschge og Nygrens undersøgelse (2009) blandt journalisterne i England og Sverige bekræfter billedet. Den viste, at de professionelle idealer bliver vigtigere og vigtigere for journalisterne som en modvægt til de strukturelle forandringer, herunder det øgede økonomiske pres.

De professionelle normer og idealer og friheden til at arbejde i overensstemmelse med disse idealer er altså centrale, fordi journalistikkens legitimitet baserer sig på de stærke professionsidealer. Derfor opridser vi herunder tre forskningsspørgsmål om, hvorvidt danske journalisters professionelle idealer og deres opfattelse af indflydelsen på deres arbejde har ændret sig over en periode, hvor de traditionelle mediehuse har været under hårdt pres.

\section{Forskningsspørgsmål}

Den journalistiske profession og privilegier som momsfrihed og mediestøtte bygger på tanken om, at journalister tjener offentligheden. Men en stor del af journalistikken varetages af medier, som også skal tjene - eller som minimum ikke tabe penge. Journalister kan således både betragte deres publikum som borgere og som forbrugere (Skovsgaard \& Bro, 2017). Der kan altså opstå spændinger mellem at tjene offentligheden og tjene penge, selvom det ikke nødvendigvis er modsætninger. Spørgeskemaundersøgelsen fra 2009, som også er en del af datagrundlaget for undersøgelsen i denne artikel, viste, at journalisterne i høj grad lagde vægt på at tjene offentligheden snarere end at skabe profit og sælge deres journalistik på linje med en hvilken som helst anden vare (Skovsgaard m.fl., 2012). Den professionelle logik blev altså vægtet højere end den økonomiske markedslogik. Spørgsmålet er, om den øgede konkurrence, som er beskrevet ovenfor, har påvirket journalisternes prioritering i 
spørgsmålet om at tjene offentligheden. Det første spørgsmål, vi søger svar på, er derfor:

Har de danske journalisters opfattelse af at tjene offentligheden ændret sig fra 2009 til 2015?

Journalister kan se deres rolle i samfundet på mange forskellige måder, og selv hvis de generelt er temmelig enige om at tjene offentligheden, så kan det også gøres på flere forskellige måder. Ideen om rolleopfattelser er netop baseret på, at journalister har flere forskellige mulige roller, som kan være mere eller mindre vigtige for dem (se Mellado m.fl., 2017, for at få en introduktion til journalistiske rolleopfattelser). Rolleopfattelser generelt - herunder også journalisters professionelle rolleopfattelser - dannes på baggrund af forventninger i omgivelserne (Biddle, 1986; Skovsgaard \& Bro, 2017; Turner, 2001). Disse forventninger udtrykkes blandt andet i debatter omkring journalistik, gennem uddannelse og på nyhedsredaktionerne, men også via de valg og prioriteringer, som borgerne eller forbrugerne foretager, når de konsumerer journalistik. På den baggrund er det nærliggende at spørge, om ændringerne i betingelserne for journalisternes arbejde og de forventninger, journalister mødes af i deres daglige arbejde, afspejler sig i en ændring i journalisternes rolleopfattelser.

Skovsgaard m.fl. (2012) viste, at danske journalister så det som deres vigtigste rolle at være en kritisk vagthund, mens det også var vigtigt, men dog mindre vigtigt, at sørge for, at borgerne kommer til orde og deltager i samfundsdebatten, mens det kun af meget få blev set som et selvstændigt mål at underholde. Hvis rollen som underholder er blevet vigtigere på bekostning af rollerne som neutral observatør eller kritisk vagthund, er det en indikation på, at det øgede fokus på at tjene penge har betydet, at en økonomisk markedslogik truer den professionelle logik.

Det andet spørgsmål, vi søger svar på, er:

Har de danske journalisters rolleopfattelser ændret sig fra 2009 til 2015? 
Én ting er journalisternes idealer om, hvordan de bør udføre deres job. Noget andet er, om de rent faktisk føler, at de har frihed til at udføre deres arbejde i en stadig mere presset mediebranche. I 2009 vurderede journalisterne, at de havde stor autonomi, og at deres arbejde var temmelig afskærmet fra eksterne faktorer såsom politisk og økonomisk indflydelse fra eksempelvis annoncører og ejere, mens de i højere grad oplevede, at interne faktorer som tidspres og deadlines samt den redaktionelle linje på deres eget medie havde indflydelse på deres arbejde.

Det kan dog tænkes, at udfordringen med at finde en velfungerende forretningsmodel i den digitale tidsalder og de deraf følgende økonomiske udfordringer har betydet, at journalisterne i 2015 oplever større indflydelse fra ejere, annoncører og fra brugerne. Vores tredje og sidste spørgsmål er:

Har de danske journalisters opfattelse af de interne og eksterne indflydelser på deres arbejde ændret sig fra 2009 til 2015?

\section{Metode}

Vi baserer analyserne på en webbaseret spørgeskemaundersøgelse blandt danske journalister i foråret 2015 og sammenligner dem med resultaterne fra en lignende spørgeskemaundersøgelse fra 2009. Undersøgelsen fra 2015 var en del af den internationale The Worlds of Journalism-undersøgelse (The Worlds of Journalism Study, 2012). En del af spørgsmålene var identiske med de spørgsmål, der blev stillet til danske journalister i undersøgelsen fra 2009. Samtidig var fremgangsmåden i dataindsamlingen den samme, hvilket giver os mulighed for at sammenligne svarene fra 2009 og 2015 og se på udviklinger over tid (se en beskrivelse af dataindsamlingen fra 2009 i Skovsgaard m.fl., 2012).Vi er dog også begrænset i sammenligningen på visse punkter, da ikke alle spørgsmål var formuleret ens, og da svarkategorierne heller ikke i alle tilfælde var identiske. I analysen vil vi gøre klart, hvordan vi håndterer de tilfælde.

Undersøgelsen fra 2015 tager udgangspunkt i definitionen af journalister fra feltmanualen til The Worlds of Journalism-manualen (The Worlds of Journalism Study, 2012): 
"En professionel journalist er en person, der tjener mindst 50 procent af sin indkomst fra betalt arbejde for nyhedsmedier og er involveret $i$ at producere og redigere journalistisk indhold eller i redaktionel ledelse og koordinering [...]. Journalister fra alle former for medier er inkluderet i populationen, inklusive aviser, magasiner, tv-stationer, radiostationer, onlinemedier og nyhedsbureauer."(Vores oversættelse).

Forudsat at organisationsgraden blandt journalister er usædvanlig høj (i 2009 anslog Dansk Journalistforbund den til 90-95 procent, selvom det naturligvis er afhængigt af definitionen, se Skovsgaard m.fl. 2012), operationaliserede vi populationen af danske journalister som medlemmer af Dansk Journalistforbund. Det er dog ikke alle medlemmer af forbundet, som passer til denne undersøgelses definition af journalister. Vi udvalgte derfor medlemmer, der hører til følgende sektioner: distriktsblade, dagblade, organisationsblade, ugeblade, radio/tv, nyhedsbureauer og internetmedier. Samtidig blev medlemmer i freelancegruppen inkluderet. Da nogle af freelancerne udelukkende arbejder med pr og ikke journalistik, startede spørgeskemaet med et filterspørgsmål, der skulle frasortere medlemmer, der ikke passede på denne undersøgelses definition af journalister.

Den 18. maj 2015 sendte vi i samarbejde med Dansk Journalistforbund en e-mail til medlemmerne med et link til spørgeskemaet. 2. juni 2015 blev der sendt en påmindelsesmail til dem, der ikke havde svaret eller kun havde svaret på dele af spørgeskemaet, så de havde mulighed for at svare, inden dataindsamlingen stoppede 9. juni 2015.

Invitationen blev sendt ud til 8.644 journalister, hvor 200 e-mails ikke nåede frem, 591 indikerede ved filterspørgsmålet, at de ikke hørte til populationen, og 413 stoppede, før de havde besvaret $50 \%$ af spørgsmålene. Herefter bestod datasættet af 1.362 journalister, hvoraf 1.280 havde besvaret hele spørgeskemaet. Dette giver en AAPOR-svarprocent på 18,9 \% (AAPOR response rate 4 , AAPOR 2015).

Denne svarprocent er baseret på en konservativ vurdering, fordi vi ikke kan være sikre på, om alle de medlemmer, som modtog spørgeskemaet, egentlig tilhører populationen for denne undersøgelse. Det første spørgsmål, når respondenten klikkede 
på linket til spørgeskemaet, skulle afklare, om vedkommende arbejdede som journalist ifølge vores definition ovenfor. 591 respondenter svarede nej og deltog derfor ikke i undersøgelsen. Blandt de mange respondenter, der aldrig klikkede sig ind i spørgeskemaet, er der efter al sandsynlighed flere af denne type respondenter, som ikke passede ind i populationen. Vi har dog ikke mulighed for at afgøre, hvem eller hvor mange blandt dem, der ikke har klikket sig ind i spørgeskemaet, som egentlig ikke tilhører populationen, og derfor indgår de i grundlaget for beregningen af svarprocenten. Det betyder, at den reelle svarprocent efter al sandsynlighed undervurderes i vores beregning.

Svarprocenten er dog - det konservative estimat til trods - i den lave ende (Johnson \& Owen, 2003). Lave svarprocenter er et stigende problem for forskning, der anvender spørgeskemaundersøgelser, herunder særligt for elitegrupper som eksempelvis politikere eller journalister. En svarprocent på omkring 20 $\%$ er ikke usædvanlig for undersøgelser i sådanne grupper (for eksempel Wiesehomeier \& Benoit, 2007), og nylige undersøgelser af journalister har endda baseret sig på svarprocenter helt ned til 5 \% (Örnebring \& Mellado, 2016). Når svarprocenten er lav, er det endnu vigtigere så vidt muligt at analysere, om respondenterne i samplet er repræsentative for populationen (Johnson \& Owen, 2003).

Vi havde med hjælp fra Dansk Journalistforbund mulighed for at foretage en frafaldsanalyse, hvor vi på en række variabler sammenlignede dem, der havde svaret på spørgeskemaet, med dem, der ikke havde svaret. En sådan analyse kan give et indtryk af, om den lave svarprocent giver problemer i forhold til, hvor repræsentativt vores sample er for populationen af danske journalister. Vores sammenligning viste, at der ikke er en statistisk signifikant forskel mellem vores sample og populationen i forhold til køn, alder og geografi, mens vi fandt en statistisk signifikant, men substantielt lille underrepræsentation af freelancere og overrepræsentation af journalister, der arbejder ved dagblade (se udvalgte resultater i tabel 1). Dermed tyder frafaldsanalysen på, at vores sample afspejler populationen af journalister uden store skævheder (det samme gjorde sig gældende i undersøgelsen fra 2009, se Skovsgaard, 2010), hvilket styrker validiteten af begge undersøgelser og sammenligningen mellem dem. 
Tabel 1. Sammenligning af respondenter og ikke-respondenter (2015-undersøgelsen).

\begin{tabular}{|c|c|c|c|}
\hline & Ikke-respondenter & Respondenter & Total \\
\hline Andel kvinder & $42,4 \%$ & $43,5 \%$ & $42,6 \%$ \\
\hline Gennemsnitlig alder & 45,37 & 45,72 & 45,43 \\
\hline Region Hovedstaden & $60,4 \%$ & $60,7 \%$ & $60,5 \%$ \\
\hline Dagblade*** & $33,6 \%$ & $39,4 \%$ & $34,7 \%$ \\
\hline Tv og radio & $35,1 \%$ & $31,9 \%$ & $34,5 \%$ \\
\hline Freelancere* $^{*} \%$ & $21,2 \%$ & $23,4 \%$ \\
\hline Laveste N $^{*} \%$ & 921 & 4.876 \\
\hline
\end{tabular}

${ }^{*} p<0,05^{* * *} p<0,001$

I de tilfælde, hvor spørgsmålene tillader en direkte sammenligning af svarene mellem de to år, har vi - for at sikre, at forskellene ikke skyldes forskelle mellem de to samples - lavet regressionsanalyser, hvor vi kontrollerer for køn, journalistisk erfaring, medietype, og om man er freelancer. Denne metode er også med til at sikre, at eventuelle skævheder, der stammer fra den lave svarprocent, ikke eliminerer validiteten af sammenligningerne mellem årene. I alle analyserne fastholdes de signifikante forskelle, når kontrolvariablerne er inkluderet. Disse ekstra analyser er således med til at styrke indtrykket af, at vores samples giver et retvisende billede af forskellene mellem de danske journalister i 2009 og 2015. For at holde fortolkningerne af vores resultater så gennemskuelige som muligt rapporterer vi ikke regressionstabellerne i analysen.

\section{Resultater}

\section{Offentlighedens tjener}

Journalisternes opfattelse af, at de bør tjene offentligheden snarere end at tænke i efterspørgsel og profit, er ikke reduceret i 2015 sammenlignet med 2009 (se tabel 2). Tværtimod er der, ligesom i USA, England og Sverige, en tendens til, at journalisterne lægger endnu mere vægt på at tjene offentligheden. Ved to af de fire spørgsmål er journalisternes gennemsnitlige score højere i 2015 i forhold til 2009. Det gælder spørgsmålene om, at journalister bør gå efter historier, som i deres professionelle vurdering 
er de vigtigste, og at en journalistisk vurdering snarere end efterspørgsel skal afgøre, hvilke historier der skal produceres. Disse forskelle er statistisk signifikante.

Tabel 2. Journalisternes opfattelse af at tjene offentligheden.

\begin{tabular}{|l|c|c|}
\hline & \multicolumn{2}{|c|}{ Gennemsnitlig score $^{1}$} \\
\hline $\begin{array}{l}\text { Journalisterne bør tjene offentligheden sna- } \\
\text { rere end at skabe profit for medierne }\end{array}$ & 2009 & 0,74 \\
\hline $\begin{array}{l}\text { Journalister bør gå efter de historier, som } \\
\text { efter deres professionelle vurdering er de } \\
\text { vigtigste for borgerne i demokratiet }\end{array}$ & $0,79^{* * *}$ & 0,74 \\
\hline $\begin{array}{l}\text { Journalistik er en vare, hvor efterspørgs- } \\
\text { len fra borgerne må bestemme, hvad der } \\
\text { produceres }\end{array}$ & 0,33 & 0,32 \\
\hline $\begin{array}{l}\text { Journalistik er en offentlig service, hvor en } \\
\text { professionel journalistisk vurdering snarere } \\
\text { end efterspørgsel skal afgøre, hvad der } \\
\text { produceres }\end{array}$ & $0,68^{* * *}$ & $0,74^{* * *}$ \\
\hline Laveste N & 1.925 & 1.357 \\
\hline
\end{tabular}

1) Målt på en skala fra 0 = "Meget uenig" til 1 = "Meget enig". Transformeret fra svarskala $(7$ punkter): $0=$ "Meget uenig" til $6=$ "Meget enig".

*** $p<0,001$

Resultaterne tyder altså ikke på, at det økonomiske pres på mediebranchen i årene mellem vores to undersøgelser har eroderet danske journalisters stærke ideal om at tjene offentligheden. Snarere tværtimod.

\section{Rolleopfattelser}

Det næste spørgsmål er, om de økonomiske og teknologiske udviklinger har påvirket den måde, journalister mener, man bør tjene offentligheden på. Det undersøger vi ved at se nærmere på journalisternes rolleopfattelser.

Man skal være forsigtig i sammenligningen af rollespørgsmålene fra 2009 til 2015. For det første er spørgsmålene i flere tilfælde formuleret lettere forskelligt. For det andet var der ved spørgsmålene i 2009 fire svarkategorier ("Ikke vigtigt", "Mindre vigtigt", "Temmelig vigtigt" og "Ekstremt vigtigt" mod fem svarkategorier i 2015 ("Ikke vigtigt", "Mindre vigtigt", "Ret vigtigt", "Meget vigtigt" og "Ekstremt vigtigt"). For at skabe det bedste grundlag for sammenligningen fokuserer vi på kategorierne "Ikke vigtigt" og "Ekstremt vigtigt". I begge undersøgelser er de 
skalaens henholdsvis laveste og højeste kategori, og ordlyden er for begge kategoriers vedkommende ens i begge undersøgelser. Dette greb afslører både, hvad journalisterne prioriterer lavt og højt, og det giver et bedre grundlag for sammenligningen, men det skal samtidig understreges, at det ikke gør tallene direkte sammenlignelige. Ikke overraskende er andelen, der svarer "Ekstremt vigtigt" generelt højere i 2009, hvor der var fire frem for fem svarkategorier, og hvor den næsthøjeste svarkategori var "Temmelig vigtigt" i stedet for "Meget vigtigt". Vi begrænser os derfor til at sammenligne mønstre i svarene på tværs af årene.

Mønstret er temmelig ensartet i 2009 og 2015 (se tabel 3 og 4). Rollen som den kritiske vagthund får stor opbakning, mens det at mobilisere folk til at deltage i demokratiet og den offentlige debat får mindre opbakning end rollen som vagthund, men dog en del opbakning. Til gengæld får rollerne som henholdsvis aktivist og underholder begrænset opbakning begge år, ligesom rollen som loyal over for magten (der kun er målt i 2015) nærmest ingen støtte får. Kun i forhold til rollen som den neutrale iagttager er der en markant forskel i prioriteringen på tværs af årene. Denne forskel skyldes dog sandsynligvis formuleringen af spørgsmålene. I 2009 blev journalisterne spurgt, hvor vigtigt det er at "spejle den offentlige mening neutralt", mens de i 2015 blev spurgt, hvor vigtigt det er at "beskrive tingene, som de er" og være en "neutral observatør". At spejle den offentlige mening neutralt fordrer, at man ved, hvad den offentlige mening er, og at den kan spejles neutralt. Svarene er derfor næppe et udtryk for, at det er blevet meget mere væsentligt at være neutral og nøgtern i 2015, end det var i 2009. Svarene fra 2015 er nærmere et udtryk for, at det at være neutral eller tilstræbt objektiv stadig er et væsentligt ideal for journalisterne, ligesom det også var i 2009 (Albæk m.fl., 2015; Skovsgaard m.fl., 2012). Denne pointe støttes også af, at journalisterne i 2015 finder det noget mere væsentligt at overvåge og granske politiske ledere end at være kritisk over for regeringen. Forskellen mellem de to skyldes formentlig, at spørgsmålet om at være kritisk over for regeringen delvist kommer i konflikt med idealet om neutralitet, fordi man kun bliver spurgt til regeringen og ikke politikere generelt, hvilket kan åbne for en modvilje mod en ubalance i den kritiske tilgang. 
Tabel 3. Journalisternes rolleopfattelse 2009.

\begin{tabular}{|c|c|c|}
\hline Neutral & $\begin{array}{l}\text { \%, der svarer } \\
\text { "Ikke vigtigt"1 }\end{array}$ & $\begin{array}{c}\% \text {, der svarer } \\
\text { "Ekstremt vigtigt" }\end{array}$ \\
\hline Spejle den offentlige mening neutralt & 5,2 & 23,2 \\
\hline \multicolumn{3}{|l|}{ Vagthund } \\
\hline $\begin{array}{l}\text { Undersøge påstande og udsagn, som kommer } \\
\text { fra regeringen }\end{array}$ & 0,7 & 57,1 \\
\hline $\begin{array}{l}\text { Være djævlens advokat i forhold til de folke- } \\
\text { valgte ved konstant at være kritisk over for } \\
\text { deres handlinger }\end{array}$ & 0,7 & 55,6 \\
\hline $\begin{array}{l}\text { Være djævlens advokat i forhold til erhvervs- } \\
\text { livet ved konstant at være kritisk over for } \\
\text { erhvervsfolkenes handlinger }\end{array}$ & 0,8 & 53,0 \\
\hline \multicolumn{3}{|l|}{ Borgerdeltagelse } \\
\hline $\begin{array}{l}\text { Motivere borgerne til at involvere sig i den } \\
\text { offentlige debat om vigtige emner }\end{array}$ & 1,6 & 28,8 \\
\hline $\begin{array}{l}\text { Give almindelige mennesker en chance for at } \\
\text { udtrykke deres holdninger til offentlige anlig- } \\
\text { gender }\end{array}$ & 1,5 & 27,6 \\
\hline $\begin{array}{l}\text { Udvikle intellektuel og kulturel interesse hos } \\
\text { borgerne }\end{array}$ & 4,5 & 21,6 \\
\hline \multicolumn{3}{|l|}{ Aktivist } \\
\hline Sætte den politiske dagsorden & 4,1 & 14,7 \\
\hline Være talerør for bestemte grupper i samfundet & 35,2 & 4,3 \\
\hline \multicolumn{3}{|l|}{ Underholde } \\
\hline Sørge for underholdning og afslapning & 12,3 & 3,8 \\
\hline $\begin{array}{l}\text { Koncentrere sig om journalistik, som interes- } \\
\text { serer det bredest mulige publikum }\end{array}$ & 11,0 & 3,5 \\
\hline Laveste N & 1.873 & 1.873 \\
\hline
\end{tabular}

1) Målt på en firepunktskala fra "Ikke vigtigt" til "Ekstremt vigtigt"

Om de enkelte rolleopfattelser nyder den samme opbakning i 2015, som de gjorde i 2009, er ikke muligt at svare på med vores data, da der er for store forskelle i formuleringerne af spørgsmål og i svarkategorierne til at drage den slags konklusioner. Vi kan dog konkludere, at der mellem 2009 og 2015 ikke er sket store forskydninger i, hvilke roller journalisterne prioriterer højt og lavt. I deres opfattelse af journalistikkens rolle i samfundet lægger journalisterne vægt på de demokratiske roller som kritiske vagthunde og som dynamoer for borgerdeltagelse i demokratiet. De opfatter sig også fortsat mere som vagthunde, der agerer på vegne af borgerne, end som nogen, der skal inddrage borgerne som deltagere i den demokratiske proces. Begge roller nyder dog betragtelig opbakning blandt journalisterne i både 2009 og 2015. Omvendt er der ikke stor støtte til, at journalister som et selvstændigt mål skal stræbe efter at påvirke politik, hvilket er i 
Tabel 4. Journalisternes rolleopfattelse 2015.

\begin{tabular}{|l|c|c|}
\hline Neutral & $\begin{array}{c}\%, \text { der svarer } \\
\text { "lkke vigtigt"1 }\end{array}$ & $\begin{array}{c}\text { \%, der svarer } \\
\text { "Ekstremt vigtigt"1 }\end{array}$ \\
\hline Beskrive tingene, som de er & 0,1 & 61,4 \\
\hline Være en neutral observatør & 3,1 & 32,2 \\
\hline Vagthund & 1,0 & 43,1 \\
\hline Overvåge og granske politiske ledere & 0,8 & 34,1 \\
\hline Overvåge og granske erhvervslivet & 9,6 & 18,5 \\
\hline Være kritiker af regeringen & & 16,5 \\
\hline Borgerdeltagelse & 3,2 & 16,4 \\
\hline $\begin{array}{l}\text { Lade almindelige borgere udtrykke deres } \\
\text { holdning om offentlige anliggender }\end{array}$ & 8,1 & 8,4 \\
\hline Sørge for dannelse blandt borgerne & 11,0 & 7,5 \\
\hline $\begin{array}{l}\text { Motivere borgerne til at deltage i politiske } \\
\text { aktiviteter }\end{array}$ & & 7,5 \\
\hline Aktivist & 8,9 & 6,6 \\
\hline Sætte den politiske dagsorden & 17,3 & 1,1 \\
\hline Være forkæmper for sociale forandringer & 17,5 & 1,0 \\
\hline Påvirke den offentlige mening & & 0,1 \\
\hline Underholde & 19,4 & 1,333 \\
\hline Levere underholdning og afslapning & 23,4 & 0,2 \\
\hline $\begin{array}{l}\text { Levere den form for nyheder, der tiltrækker } \\
\text { det største publikum }\end{array}$ & & \\
\hline Loyal over for magten & 90,4 & \\
\hline Støtte regeringens politik & 79,5 & \\
\hline $\begin{array}{l}\text { Præsentere et positivt billede af de politi- } \\
\text { ske ledere }\end{array}$ & 1,333 & \\
\hline Laveste N & & \\
\hline I) & & \\
\hline
\end{tabular}

1) Målt på en fempunktskala fra "Ikke vigtigt" til "Ekstremt vigtigt"

overensstemmelse med tanken om, at journalister opfatter det som vigtigt at være neutrale og nøgterne i deres beskrivelser af verden. Ligesom i 2009 bakker de i 2015 i lav grad op om rollerne som underholdere. I alle tilfælde svarer færre end fire procent af journalisterne, at disse roller er "Ekstremt vigtige". Altså har journalisternes eget syn på deres professionelle roller ikke ændret sig mærkbart fra 2009 til 2015 i en periode, hvor der har været markante økonomiske og teknologiske udviklinger.

\section{Indflydelse på journalisternes arbejde}

At ændringerne i journalisternes idealer fra 2009 til 2015 ser ud til at være begrænsede, udelukker ikke, at journalisternes autonomi og mulighed for at efterleve deres idealer er forandret hen over de år, hvor mediebranchen og den journalistiske 
profession har oplevet markante udviklinger i betingelserne for deres arbejde. Man kunne således forestille sig en situation, hvor de professionelle idealer er intakte, men presset på dem ifølge journalisternes opfattelse er højere, end det var tidligere. Det er i hvert fald tilfældet i USA (Willnat \& Weaver, 2014).

Vi har både i 2009 og 2015 stillet journalisterne spørgsmål om, i hvor høj grad en række faktorer har indflydelse på deres daglige arbejde. Vi har i denne analyse kun medtaget de spørgsmål, der blev stillet både i 2009 og 2015. Man skal dog være en smule forsigtig i sammenligningen mellem de to år. For det første er der små ændringer i formuleringerne af nogle af spørgsmålene (se noter til tabel 5). For det andet giver svarskalaen i 2009 med sine 11 punkter mulighed for mere finjusterede svar end skalaen i 2015, der havde fem punkter. Begge skalaer gik dog fra "slet ingen indflydelse" i den ene ende til "meget stor indflydelse" i den anden ende, og de havde begge et naturligt midtpunkt, så vi har transformeret dem til at gå fra 0 = "slet ingen indflydelse" til 1 = "meget stor indflydelse", så vi har sammenlignelige scorer på tværs af de to undersøgelser.

Tabel 5. Sammenligning af indflydelse på journalisternes arbejde 2009-2015.

\begin{tabular}{|c|c|c|}
\hline & \multicolumn{2}{|c|}{ Gennemsnitlig score $^{1}$} \\
\hline Interne faktorer i organisationen & 2009 & 2015 \\
\hline Deadlines $^{2}$ & $0,64^{* * *}$ & $0,72^{* * *}$ \\
\hline Dit medies redaktionelle linje & $0,51^{* * *}$ & $0,66^{* * *}$ \\
\hline Dit medies ejere ${ }^{3}$ & $0,31^{* * *}$ & 0,26 *** \\
\hline \multicolumn{3}{|c|}{ Eksterne faktorer i forhold til organisationen } \\
\hline Konkurrence med andre medier ${ }^{4}$ & $0,51^{* * *}$ & $0,36^{* * *}$ \\
\hline Oplags-/læser-/seer-/lyttertal ${ }^{5}$ & $0,49 * * *$ & $0,42^{* * *}$ \\
\hline Kommentarer fra læsere/seere/lyttere ${ }^{6}$ & $0,38^{* * *}$ & $0,41^{* * *}$ \\
\hline Annoncører $^{7}$ & $0,24 * * *$ & $0,16^{* * *}$ \\
\hline Laveste $\mathrm{N}$ & 1.514 & 1.197 \\
\hline
\end{tabular}

1) Spørgsmål: "Hvor stor indflydelse har de følgende faktorer på dit daglige arbejde som journalist?" Målt på en skala fra 0 = "Slet ingen indflydelse" til 1 = "Meget stor indflydelse". Transformeret fra svarskala 2009 (11 punkter): 0 = "Slet ingen indflydelse" til 10 = "Meget stor indflydelse" og 2015 (fem punkter): 0 = "Ingen indflydelse" til 4 = "Meget stor indflydelse".

2) Formulering 2009: "Tidspres/deadlines"; 2015: "Deadlines"

3) Formulering 2009: "Dit medies aktionærer/ejere"; 2015: "Dit medies ejere"

4) Formulering 2009: "Konkurrence med andre medier"; 2015: "Konkurrerende medier"

5) Formulering 2009: "Oplags-/læser-/seer-/lyttertal"; 2015: "Undersøgelser af eller data om læsere/lyttere/seere/brugere"

6) Formulering 2009: "Kommentarer fra læsere/seere/lyttere"; 2015: "Feedback fra publikum"

7) Formulering 2009: "Annoncører"; 2015: "Annonce- og reklamehensyn" *** $p<0,001$ 
At transformere to skalaer til en samlet skala betyder selvfølgelig ikke, at man skal smide forsigtigheden over bord, når man fortolker sammenligningerne mellem årene. Men da den gennemsnitlige score i nogle tilfælde er højere i 2015 end i 2009 og i andre tilfælde lavere, er der i hvert fald ikke en systematisk skævhed på grund af forskellene i svarkategorier mellem årene. Derfor fortæller sammenligningerne også med en vis forsigtighed i fortolkningerne noget om udviklingerne mellem 2009 og 2015.

I 2015 har deadlines fået større indflydelse i det daglige arbejde end i 2009, hvilket giver god mening, da publicering på flere platforme er blevet hverdag for en stor del af journalisterne. Mediets redaktionelle linje ser også ud til at have fået større indflydelse, mens det er ganske overraskende, at konkurrence med andre medier og hensynet til publikumstal er blevet mindre. Selvom det kan spille ind, at spørgsmålsformuleringen ikke er helt ens, ser det ud til, at journalisterne ikke nødvendigvis oplever, at den øgede konkurrence beskrevet i teorien ovenfor har en større indflydelse på det daglige arbejde. Heller ikke kommentarer og feedback fra publikum, som der ellers har været stort fokus på gennem de senere år under betegnelsen web 2.0, ser ud til at være blevet markant vigtigere fra 2009 til 2015. Resultaterne indikerer altså, at journalisterne føler sig mere tidspressede af deadlines, og at den redaktionelle linje er blevet en mere tydelig indflydelse i det daglige arbejde. Omvendt ser det ikke ud til, at det økonomiske pres, medierne har været udsat for mellem 2009 og 2015, har resulteret i, at journalisterne føler konkurrencepresset mere intenst, og heller ikke, at publikum har fået større indflydelse på deres daglige arbejde. Selvom disse konklusioner må drages med forbehold for forskellene i spørgsmålsformuleringer og svarskalaer, er resultaterne lettere overraskende, da de på nogle punkter strider mod det pessimistiske billede, der ofte tegnes af journalistikkens udvikling.

\section{Diskussion}

Journalister arbejder i en mediebranche, som på mange måder er under pres. Alle har mulighed for at publicere information via internettet og særligt sociale medier, og konkurrencen er øget for 
de traditionelle medier. Mange har advaret om en nedadgående spiral med vægt på hurtige klik, tabloide nyheder og vigende kvalitet. Og ifølge en tidligere undersøgelse oplever journalisterne også selv et stigende produktionspres og faldende journalistisk kvalitet (Mollerup m.fl., 2016). Litteraturen påpeger også, at en økonomisk markedslogik kan risikere at undergrave de idealer, som journalistikkens professionelle logik bygger på (for eksempel Hallin, 2000; Freidson, 2001).

Set i det lys er vores resultater overraskende. I 2015 såvel som i 2009 støtter journalisterne de samme høje idealer om at arbejde i offentlighedens interesse frem for ensidigt at styre efter forbrugernes efterspørgsel, hvad end den måtte være, og på den måde skabe profit. Rollen som vagthund dominerer stadig efterfulgt af rollen som katalysator for borgerdeltagelse i demokratiet. Samtidig er der begrænset støtte til et rolleideal som underholder. Én ting er dog, at de høje idealer stadig lever trods en presset tid i mediebranchen. Noget andet er, at journalisterne tilsyneladende ikke oplever konkurrencen fra andre medier eller hensynet til antallet af læsere/lyttere/seere/brugere som en mere væsentlig indflydelse på deres daglige arbejde i 2015, end de gjorde i 2009. Dog viser resultaterne, at journalisterne i 2015 oplever mere pres fra deadlines og fra mediets redaktionelle linje end i 2009. Det indikerer, at presset på dagligdagen mest kommer til udtryk i de direkte, interne betingelser for det journalistiske arbejde i den eller de medieorganisationer, journalisterne arbejder for.

Overordnet peger vores resultater på en temmelig stor stabilitet fra 2009 til 2015 i både journalisternes idealer og det pres, de føler på deres daglige arbejde. Det, til trods for at mediebranchen har været gennem en rivende udvikling henimod mere publicering på hjemmesider og sociale medier end tidligere og et generelt indtryk af krise og nedskæringer hos de traditionelle mediehuse, der kæmper med at finde den rette forretningsmodel under de nye betingelser. Man kan ikke med vores resultater i hånden afvise, at der i dag er problematiske forhold for at producere journalistik, eller at den journalistiske kvalitet er dalende, ej eller at disse problemer vil blive mere markante over tid. Man kan dog konstatere, at når journalisterne er spurgt med seks års mellemrum frem for at give en retrospektiv vurdering, ser det ikke ud til, at den journalistiske profession med de idealer, der 
er knyttet til den, og det pres, der er på journalisternes daglige arbejde, er inde i en nedadgående spiral, som ender med en hård mavelanding på bunden. På den måde stemmer resultaterne godt overens med hovedkonklusionerne i en stor undersøgelse af den journalistiske kvalitet i danske nyhedsmedier. Den viste en stigning i antallet af kilder i historierne og en stabil andel af hard news (Willig m.fl., 2015). Det er dog en udvikling, som bør følges tæt, da der helt åbenlyst for øjeblikket og også inden for en overskuelig fremtid ikke er ro og stabilitet i mediebranchen og blandt journalisterne, som traditionelt har leveret en væsentlig råvare i demokratiet.

\section{REFERENCER}

Albæk, Erik, van Dalen, Arjen, Pihl-Thingvad, Signe, Skovsgaard, Morten \& de Vreese, Claes H. (2015). Den Danske journalist: Voerdier, produktion, indhold, Odense: Syddansk Universitetsforlag.

Aldridge Meryl \& Evetts, Julia (2003). "Rethinking the concept of professionalism: The case of journalism”, British Journal of Sociology, 54 . årgang, nr. 4, pp. 547-564.

Bakker, Piet (2012). "Aggregation, content farms and Huffinization. The rise of low-pay and no-pay journalism”, Journalism Practice, 6. årgang, nr. 5-6, pp. 627-637.

Bernard, H. Russell, Killworth, Peter, Kronenfeld, David \& Sailer, Lee (1984). "The problem of informant accuracy: The validity of retrospective data", Annual Review of Anthropology, 13. årgang, pp. 495-517.

Blach-Ørsten, Mark (2013). “The emergence of an increasingly competitive news regime in Denmark", pp. 93-110 i Raymond Kuhn \& Rasmus Kleis Nielsen (red.), Political journalism in transition: Western Europe in a comparative perspective, London: I.B. Tauris.

Biddle, Bruce J. (1986). "Recent developments in role theory", Annual Review of Sociology, 12. årgang, pp. 67-92.

Cook, Timothy (1998). Governing with the news: The news media as a political institution, Chicago, IL: University of Chicago Press.

Elmelund-Præstekær, Christian, Hopmann, David N., \& Nørgaard, Asbjørn S. (2011). "Does mediatization change MP-media interaction and MP attitudes towards the media? Evidence from a Longitudinal Study of Danish MPs", International Journal of Press/Politics, 16. årgang, nr. 3, pp. 382-403. 
Deuze, Mark (2005). "What is journalism? Professional identity and ideology reconsidered”, Journalism, 6. årgang, nr. 4, pp. 442-464.

Franklin, Bob (2014). "The future of journalism. In an age of digital media and economic uncertainty”, Journalism Studies, 15. årgang, nr. 5, pp. 481-499.

Freidson, Eliot (2001). Professionalism. The third logic, Cambridge: Polity Press.

Hallin, Daniel C. (2000). "Commercialism and professionalism in the American news media”, Mass media and society, 3. årgang, pp. 243-262.

Hallin, Daniel and Mancini, Paolo (2004). Comparing media systems: Three models of media and politics, Cambridge: Cambridge University Press.

Hartley, Jannie M. (2011). Radikalisering af kampzonen. En analyse af netjournalistisk praksis og selvforståelse i spoendingsfeltet mellem idealer og publikum. Ph.d.-afhandling, Roskilde: Roskilde Universitet.

Johnson, Timothy \& Owens, Linda (2003). Survey response rate reporting in the professional literature. 58th Annual Meeting of the American Association for Public Opinion Research, Nashville (paper presentation).

Kammer, Aske (2013). “The mediatization of journalism”, MedieKultur: Journal of media and communication research, 29. årgang, nr. 54, pp. 141-158.

Kragh, Claus (2014). "Mediernes kapløb mod bunden”. mm.dk, 13. januar. https://www.mm.dk/artikel/mediernes-kaploeb-mod-bunden (besøgt 12. september 2017).

Levy, David, A. L. \& Nielsen, Rasmus Kleis (red.) (2010). The changing business of journalism and its implications for democracy, Oxford: Reuters Institute for the Study of Journalism.

Nielsen, Rasmus Kleis (2012). Ten years that shook the media world, Oxford: Reuters Institute for the Study of Journalism.

Larsen, Alex F. (2016). ”Journalistikken er på afveje”, Politiken.dk, 17. januar. http://politiken.dk/debat/debatindlaeg/art5607173/Journalistikken-erp\%C3\%A5-afveje (besøgt 12. september 2017).

McManus, John H. (1997). “Who's responsible for journalism?”, Journal of Mass Media Ethics, 12. årgang, nr. 1, pp. 5-17.

Mellado, Claudia, Hellmueller, Lea \& Donsbach, Wolfgang (red.).Journalistic role performance. Concepts, contexts, and methods, London: Routledge.

Mollerup, Jacob, Bro, Peter, Jørgensen, Søren S. \& Andersen, Kim (2016). Mediernes tilstandsrapport 2016. Den Danske Publicistklub \& Center for Journalistik, Syddansk Universitet.

Nillson, Monica L. (2007). "Redaktionell förädring och arbetsmiljön”, pp. 
67-78 i Kent Asp (red.), Den svenske journalistkåren, Göteborg: Göteborgs Universitet.

Pudney, Stephen (2011). "Perception and retrospection: The dynamic consistency of responses to survey questions on wellbeing”, Journal of public economics, 95. årgang, nr. 3-4, pp. 300-310.

Reuters Institute for the study of journalism (2015). Digital news report 2015. Tracking the future of news, Oxford: Reuters Institute for the study of journalism.

Schrøder, Kim, Blach-Ørsten, Mark \& Burkal, Rasmus (2017) Danskernes brug af nyhedsmedier 2017, Roskilde: Roskilde University, Center for nyhedsforskning.

Skadhede, Jørgen (2016a). ”Journalistik er et ædelt fag under et helt enormt pres", Journalisten.dk, 24. maj. http://journalisten.dk/journalistik-er-etaedelt-fag-under-et-helt-enormt-pres (besøgt 12. september 2017).

Skadhede, Jørgen (2016b). "Hvor længe overlever de store aviser på papir", Journalisten.dk, 7. januar. http://journalisten.dk/hvor-laenge-overleverde-store-aviser-paa-papir (besøgt 12. september 2017).

Slots- og Kulturstyrelsen (2017). Globaliseringen af den danske mediebranche.Analyserafinternationaleaktørers betydningfordetdanske mediemarked, danske medieudbydere og dansk medieindhold. https:// slks.dk/fileadmin/user_upload/dokumenter/medier/Mediernes_ udvikling/2017/Specialrapporter/Internationale_aktoerer/Rapport_og_ bilag/Final_Final_rapport_4.9.2017.pdf (besøgt 13. september 2017).

Skovsgaard, Morten (2010). Den Danske journalist. Ph.d.-afhandling, Odense: Syddansk Universitet.

Skovsgaard, Morten \& Bro, Peter (2011). "Preference, principle and practice: Journalistic claims for legitimacy”, Journalism Practice, 5. årgang, nr. 3, pp. 319-331.

Skovsgaard, Morten, Albæk, Erik, Bro, Peter, de Vreese, Claes H. (2012). "Media professionals or organizational marionettes: Professional values and constraints of Danish journalists", pp. 155-170 i David H. Weaver \& Lars Willnat (red.), The global journalist in the 21st Century, London: Routledge.

Skovsgaard, Morten \& Bro, Peter (2017). "Journalistic roles in the mediated public sphere”, pp. 60-74 i Claudia Mellado, Lea Hellmueller, Wolfgang Donsbach (red.), Journalistic role performance. Concepts, contexts, and methods. London: Routledge.

The Worlds of Journalism Study (2012). Field Manual. http://www. worldsofjournalism.org/research/2012-2016-study/methodological- 
documentation/ (besøgt 12. september 2017).

Tumber, Howard \& Prentoulis, Marina (2005). "Journalism and the making of a profession”, pp. 58-74 i Hugo de Burgh (red.), Making journalists, London: Routledge.

Turner Ralph H. (2001). "Role theory”, pp. 233-254 i Jonathan H. Turner (red.), Handbook of Sociological Theory, New York: Springer.

$\mathrm{Vu}$, Hong T. (2014). “The online audience as gatekeeper: The influence of reader metrics on news editorial selection”, Journalism, 15. årgang, nr. 8, pp. 1094-1110.

Weaver, David H. \& Willnat, Lars (red.) (2012). The global journalist in the 21st Century, London: Routledge.

Wiesehomeier, Nina \& Benoit, Kenneth (2007). "Presidents, parties and policy competition”, Journal of Politics, 71. årgang, nr. 4, pp. 1435-1447.

Willig, Ida, Ørsten, Mark, Hartley, Jannie M., \& Flensburg, Sofie (2015). Journalistiske kvaliteter 1999-2014: Specialrapport. København: Kulturstyrelsen.

Willnat, Lars and Weaver, David (2014). The American journalist in the digital age: Key findings, Bloomington, In: School of Journalism, Indiana University.

Witschge, Tamara \& Nygren, Gunnar (2009). "Journalistic work: a profession under pressure?”, Journal of Media Business Studies, 6. årgang, nr. 1, pp. 37-59.

Örnebring, Henrik \& Mellado, Claudia (2016). "Valued skills among journalists: An exploratory comparison of six European nations", Journalism, 19. årgang, nr. 4, pp. 445-463.

\section{FORFATTERE}

Morten Skovsgaard

Professor mso ved Center for Journalistik, Syddansk Universitet skh@sam.sdu.dk

Arjen van Dalen

Professor mso ved Center for Journalistik, Syddansk Universitet avd@sam.sdu.dk

Katrine Bisgaard

Cand.scient.pol. katrinebisgaard@me.com 